\title{
Reaction of soybean cultivars to Meloidogyne javanica and Meloidogyne incognita
}

\author{
Valéria Cecília Ghissi Mazzetti ${ }^{1}$, Gustavo Luiz Visintin ${ }^{1}$, Igor Pirez Valério², \\ Juliane Nicolodi Camera ${ }^{3 * \mathbb{D}}$, Carolina Cardoso Deuner ${ }^{l}$, Pedro Luiz Martins Soares ${ }^{4}$ \\ $10.1590 / 0034-737 X 201966030008$
}

\begin{abstract}
Nematodes of the genus Meloidogyne are associated with soybean cultivation, unknown the reaction of cultivars. The objective of this work was to determine the reaction of soybean cultivars to M. javanica and M. incognita. Twenty-seven soybean cultivars were sown in plastic pots, in a completely randomized experimental design with eight replicates. Ten days after emergence of the seedlings, in a separate experiment, $M$. javanica and $M$. incognita were inoculated. For M. javanica, cultivars classified as susceptible were BMX Lança IPRO, AMS Tibagi RR, BMX Vanguarda IPRO, NS 6700 IPRO, BMX Ativa RR, FPS Solimões RR, TEC 6702 IPRO, NS 5909 RR, NS 5445 IPRO, 54 i52 RSF IPRO, M 6410 IPRO and NS 5959 IPRO and BMX Elite IPRO, NA 6211 RR, BMX Valente RR, FPS Júpter RR, FPS Iguaçú RR, BMX Tornado RR, GMX Cancheiro RR, TMG 7161 IPRO, TMG 7062 IPRO, FPS Solar RR, M 5730 IPRO, DM5958 RSF IPRO, NS 6006 IPRO, SYN 1163 RR and M 5947 IPRO were resistant. Regarding M. incognita, the resistant cultivars were FPS Iguaçú RR, FPS Solar IPRO, SYN 1163 RR and TMG 7062 IPRO. The cutlivars FPS Júpter RR, SYN 1163 RR e TMG 7062 IPRO were resistant to both nematodes.
\end{abstract}

Keywords: reproduction factor; resistance; root-knot nematode; susceptibility.

\section{INTRODUCTION}

Phytonematodes are soil pathogens. Their control is difficult to be achieved and requires high costs for Brazilian farming production. The nematodes of the genus Meloidogyne are among the phytonematodes most frequently associated with soybean cultivation with a wide geographic distribution. They are responsible for raising the losses, mainly caused by the expansion of soybean cultivation to new agricultural frontiers, intensification of monoculture and the adoption of inadequate management practices of these pathogens (Juhász et al., 2013). For this genus, more than 80 species are described, and the main ones for the soybean crop are Meloidogyne javanica (Treub, 1885) and Meloidogyne incognita (Kofoid \& White, 1919) Chitwood, 1949 (Miranda et al., 2011). The most common species is $M$. javanica, which has a widespread occurrence and causes losses of $10 \%$ to $40 \%$ in sandy or medium-sandy soils. This nematode predominates in areas previously cultivated with coffee or cotton and is associated with succession of soybeancotton and soybean-corn crops (Miranda et al., 2011).

The typical symptom of an attack by a Meloidogyne nematode is hyperplasia, that is, thickening of the cells of the root cortex named gall. As a reflex symptom, the leaves of the attacked plants may show yellowing due to nitrogen deficiency and also chlorotic spots or necrosis between the veins, which characterizes "carijó" leaf (Deuner et al., 2012).

For a successful controlling of phytonematodes, several alternatives can be used, but most of them are limited by factors such as: habitat type (soil and root interior), morphological characteristics (presence of resistant cuticle), and polyphagous habit of feeding on several plant

\footnotetext{
Submitted on January $09^{\text {th }}, 2019$ and accepted on June $24^{\text {th }}, 2019$.

1 Students at Agronomy Graduation course of Universidade de Passo Fundo, Passo Fundo, Rio Grande do Sul, Brazil. val_ghissi@ hotmail.com; igorvalerio@gmail.com; carolinadeuner@upf.br ${ }^{2}$ Breeder at OR Sementes, Passo Fundo, Rio Grande do Sul, Brazil.

${ }_{3}^{3}$ Professional Master Science Program in Rural Development at Universidade de Cruz Alta, Cruz Alta, Rio Grande do Sul, Brazil. jcamera@unicruz.edu.br

${ }^{4}$ Universidade Estadual Paulista “Julio de Mesquita Filho", Jaboticabal, São Paulo, Brazil. pedrolms@fcav.unesp.br

*Corresponding author: ju_camera@yahoo.com.br
}

Rev. Ceres, Viçosa, v. 66, n.3, p. 220-225, mai/jun, 2019 
species (Soares et al., 2016). In the integrated management, associated strategies such as cultural control (crop rotation), genetic control (resistant cultivars), chemical control (nematicides) and biological control (fungi and bacteria) should be used (Almeida et al., 2005). Therefore, the plant genetic improvement has been developing soybean cultivars with high productivity, wide adaptation and good resistance/tolerance to pathogens. Genetic resistance is one of the best ways to control nematodes that is why it has easy assimilation by farmers, does not increase production costs and does not environmental cost of using pesticides (Teixeira, 2013).

In spite of this, many breeders do not have the information of the reaction of the cultivar to the nematodes, although this information is of fundamental importance to compose the integrated management of nematodes. There are still several cultivars whose responses (resistant or susceptible) to the nematodes of the genus Meloidogyne are still not known.

Therefore, the objective of this work is to determine the reaction of soybean cultivars to $M$. javanica and $M$. incognita.

\section{MATERIALAND METHODS}

Two experiments were carried out, one for each nematode, where 27 soybean cultivars were selected (Table 1), indicated for the southern region of Brazil, for which no information is available or there is partial information on the reaction to $M$. javanica and $M$. incognita by the breeding companies of the cultivars. Crotalaria (Crotalaria spectabilis Roth.) and tomato (Solanum lycopersicum L.) cv. Santa Cruz Kada were included in the experiment as resistance and susceptibility patterns, respectively.

In order to conduct the experiment, the seeds of the soybean cultivars were sown in plastic containers with a capacity of $5 \mathrm{~L}$ using a mixture of sterilized sand and soil (3: 1$)$.

The populations of $M$. javanica and M. incognita were originated from the municipalities of Piacatú/SP and Barreiras/BA, respectively. They were purified and multiplied in cv. Santa Cruz Kada tomato plants and kept in a greenhouse. Ten days after the emergence of soybean plants (DAE), manual thinning was performed, maintaining two plants per pot. Each plant was inoculated with a suspension of 5000 eggs and juveniles of second stage (J2) per $\mathrm{mL}$. The inoculum was obtained by washing and grinding the roots of tomato in sodium hypochlorite solution $(0.5 \%)$, according to the methodology described by Hussey \& Barker (1973) and adapted by Bonetti \& Ferraz (1981). The egg suspension and $\mathrm{J} 2$ were deposited in a hole about $3 \mathrm{~cm}$ deep next to each plant in the pot. After inoculation, the plants were maintained for 90 days in a greenhouse and watered daily, maintaining the adequate moisture level in the soil for plant growth. The temperature in this period in the greenhouse ranged from 14 to $32{ }^{\circ} \mathrm{C}$.

After 90 days, the eggs and $\mathrm{J} 2$ present in the root system of each plant were extracted according to methodology of Hussey \& Barker (1973) adapted by Bonetti \& Ferraz (1981). This same procedure was performed for each of the nematode species in the evaluated soybean cultivars. The number of eggs and J2 present in the suspension of each replicate were counted using an optical microscope (magnification 100x) with the aid of a Peters chamber. Subsequently, the Reproduction Factor (RF) was determined by the division of the Final Population (FP) by the Initial Population (PI) (Oostenbrink, 1966). Behavior of each cultivar was classified according to the criterion established by Oostenbrink (1966), and cultivars that obtained RF greater than or equal to 1 were considered susceptible, whereas those that obtained RF less than 1 were considered resistant.

The experiments were conducted in a completely randomized experimental design with eight replicates. The data achieved in the experiment were transformed into square roots of $\mathrm{X}+0.5$ and submitted to analysis of variance. The averages were grouped by the Scott-Knott test at $5 \%$ probability of error through the statistical program Assistat version 7.7 beta (pt) (Silva \& Azevedo, 2002).

\section{RESULTS AND DISCUSSION}

In the M. javanica nematode test (Table 2), the final nematode population (FP) of the soybean cultivars ranged from 250 to 13,044 individuals per plant, and this was observed for cultivars M 5947 IPRO and BMRO IPRO, respectively. The standard of susceptibility (tomato) used had a final population (FP) of 188.856 and resistance (crotalaria) of 40, with a reproductive factor (RF) of 37.8 and 40, respectively.

Based on the final population, it was verified that the highest value of this variable was obtained in the BMX cultivars IPRO, AMS Tibagi RR, BMX Vanguarda IPRO, NS 6700 IPRO, BMX Ativa RR and SPS Solimões RR, with no statistical difference between them, but with difference for the other cultivars, tomato and crotalaria. The lowest final population value was observed for cultivar M 5947 IPRO, which did not differ statistically from crotalaria, but differed from other cultivars and from tomato

In relation to the reproduction factor $(\mathrm{RF})$, and by taking into account the cultivar classification criterion proposed by Oostenbrink (1966), the reaction of soybean cultivars to $M$. javanica can be separated into two groups (Table 2). The first one is made up by susceptible cultivars that had RF between 1.0 and 2.6, being these BMX Lance IPRO, AMS Tibagi RR, BMX Vanguard IPRO, NS 6700 IPRO, BMX Active RR, FPS Solimões RR, TEC 6702 IPRO, 
NS 5909 RR, NS 5445 IPRO, 54 i52 IPRO RSF, M 6410 IPRO and NS 5959 IPRO. In the second group, the resistant cultivars with RF between 0 and 0.8 , which were BMX Elite IPRO, NA 6211 RR, BMX Valente RR, FPS Jupter RR, FPS Iguaçú RR, BMX Tornado RR, GMX Cancheiro RR, TMG 7161 IPRO, TMG 7062 IPRO, FPS Solar RR, M 5730 IPRO, DM5958 IPRO RSF, NS 6006 IPRO, SYN 1163 RR and M 5947 IPRO. Therefore, it was observed that $44.4 \%$ of the cultivars were considered susceptible, while $55.6 \%$ were resistant to $M$. javanica.

Regarding M. incognita (Table 3), the final population in the soybean cultivars varied from 2,995 to 34,600 individuals per plant. These results were observed for cultivars TMG 7062 IPRO and NS 6211 RR, respectively. The susceptibility pattern (tomato) had a PF of 137.036 and the resistance (crotalaria) of 50 with RF of 27.4 and 0.0 , respectively. The largest value of this variable was verified for the cultivar NS 6211 RR, which differed statistically from the other cultivars and the resistance and susceptibility patterns. The lowest value was for the cultivars FPS Iguaçú RR, FPS Solar IPRO, SYN 1163 RR and TMG 7062 IPRO.

Two groups were separated according to the cultivar classification criterion proposed by Oostenbrink (1966).
The first group refers to the group of susceptible cultivars (RF of 1.0 to 6.9), and the second group was composed of the resistant ones (RF between 0.6 and 0.8 ). In the second group were the cultivars FPS Iguaçú RR, FPS Solar IPRO, SYN 1163 RR and TMG 7062 IPRO, and in the first group, the other cultivars. Thus, out of the 27 soybean cultivars evaluated, $85.2 \%$ were susceptible and $14.8 \%$ were resistant to $\mathrm{M}$. incógnita.

Cultivars FPS Jupiter RR, SYN 1163 RR and TMG 7062 IPRO were classified as resistant to both nematodes.

According to Faria et al. (2003), one of the mechanisms of resistance is the accumulation of phytoalexin in resistant hosts, which coincides with the hypersensitivity reaction, thus functioning as nematostatic phytoalexins, drastically affecting nematode function and preventing its development. In studies by Mattos (2013), hostability, aggressiveness and virulence are factors that interfere with the interspecific variation of Meloidogyne species in the plant-nematoid interaction. According to Silva (2001), the suppression of nematode development and reproduction varies according to the resistance and susceptibility of the plants, and plants that are considered highly resistant allow very low reproduction rates, while

Table 1: Description of commercial soybean cultivars with their respective characteristics

\begin{tabular}{|c|c|c|c|}
\hline Cultivar & Breeder & Growth habit & Maturation Groupo \\
\hline 54i52 RSF IPRO & GDM Genética do Brasil & Undetermined & 5.4 \\
\hline AMS Tibagi RR & Bayer S.A. & Semi-Determined & 5.0 \\
\hline BMX Ativa RR & Brasmax & Determined & 5.6 \\
\hline BMX Elite IPRO & Brasmax & Undetermined & 5.5 \\
\hline BMX Lança IPRO & Brasmax & Undetermined & 5.8 \\
\hline BMX Tornado RR & Brasmax & Undetermined & 6.2 \\
\hline BMX Valente RR & Brasmax & Undetermined & 6.7 \\
\hline BMX Vanguarda IPRO & Brasmax & Undetermined & 6.0 \\
\hline DM RSF 5958 IPRO & Don Mario & Undetermined & 5.8 \\
\hline FPS Iguaçu RR & Fundação Pró-sementes & Undetermined & 5.0 \\
\hline FPS Júpiter RR & Fundação Pró-sementes & Undetermined & 5.9 \\
\hline FPS Solar IPRO & Fundação Pró-sementes & Undetermined & 6.3 \\
\hline FPS Solimões RR & Fundação Pró-sementes & Undetermined & 5.7 \\
\hline GMX Cancheiro RR & Gmax Genética & Undetermined & 6.2 \\
\hline M 5730 IPRO & Monsoy & Undetermined & 5.7 \\
\hline M 5947 IPRO & Monsoy & Undetermined & 5.9 \\
\hline M 6410 IPRO & Monsoy & Undetermined & 6.4 \\
\hline NS 5445 IPRO & Nidera & Undetermined & 5.4 \\
\hline NA 5909 RG & Nidera & Undetermined & 6.2 \\
\hline NS 5959 RG & Nidera & Undetermined & 6.9 \\
\hline NS 6006 IPRO & Nidera & Undetermined & 5.7 \\
\hline NS 6211 RR & Nidera & Determined & 6.2 \\
\hline NS 6700 IPRO & Nidera & Undetermined & 7.1 \\
\hline SYN 1163 RR & Syngenta & Undetermined & 6.3 \\
\hline TEC 6702 IPRO & CCGL TEC & Undetermined & 6.7 \\
\hline TMG 7062 IPRO & $\mathrm{TMG}^{1}$ & Semi-determined & 6.2 \\
\hline TMG $7161 \mathrm{RR}$ & $\mathrm{TMG}^{1}$ & Undetermined & 5.9 \\
\hline
\end{tabular}

${ }^{1}$ Tropical Melhoramento e Genética; Source: Registro Nacional de Cultivares (MAPA). 
the susceptible ones allow nematodes to reproduce abundantly.

In a study developed by Moritz et al. (2008), it was observed on the eighth day after inoculation that most of the nematodes that had penetrated the roots of the susceptible and resistant soybean cultivars were still at the $\mathrm{J} 2$ developmental stage, remaining parallel to the central cylinder of the roots. This could indicate that resistance mechanisms of the resistant cultivar were not yet slowing the overall development of the nematode. Similarly, Moura et al. (1993) observed that in soybean cultivars resistant to $M$. incognita, the root cells became disorganized and necrotic, and the formation of the feeding sites did not occur, preventing the development of the nematode to the $\mathrm{J} 3$ stage 10 days after inoculation.

In a study by Dalla Favera (2014), it was verified that out of the 45 soybean cultivars evaluated, in order to determine the reaction to $M$. javanica, all were susceptible. Furthermore, the highest density of phytonematodes per gram of roots was obtained in cultivar AMS Tibagi RR., data similar to those of the present study, where this cultivar proved to be one of the most susceptible for both $M$. javanica and $M$. incognita. Among the six soybean cultivars evaluated by Kirsch (2016), all presented RF greater than 1, being classified as susceptible to $M$. javanica; however, the cultivar BMX Turbo RR showed to be resistant to some populations of $M$. javanica, with RF less than 1 . In studies by Santos \& Soares (2009), although many soybean cultivars were considered susceptible, they showed values of FR close to 1 , which is less susceptible to $M$. javanica and $M$. arenaria (Neal, 1889) Chitwood, 1949. Therefore, it is suggested that in the absence of cultivars resistant to root-knot nematodes, cultivars with lower FR should be used because of the lower susceptibility presented by them. According to Alves et al. (2011), cultivars with high RF or greater than one, are susceptible and should be avoided in areas with nematode presence, especially

Table 2: Nematode final population (egg and J2/plant), reproduction factor (RF) and reaction (R) of twenty-seven soybean cultivars to Meloidogyne javanica at 90 days after inoculation

\begin{tabular}{|c|c|c|c|}
\hline Cultivar & Final population (FP) & Reproduction factor (FR) & Classification $^{4}$ \\
\hline Tomate $^{1}$ & $188,856 \mathrm{a}^{2,3}$ & 37.8 & Susceptible \\
\hline BMX Lança IPRO & $13,044 \mathrm{~b}$ & 2.6 & Susceptible \\
\hline AMS Tibagi RR & $12,630 \mathrm{~b}$ & 2.5 & Susceptible \\
\hline BMX Vanguarda IPRO & $11,635 \mathrm{~b}$ & 2.3 & Susceptible \\
\hline NS 6700 IPRO & $11,262 \mathrm{~b}$ & 2.3 & Susceptible \\
\hline BMX Ativa RR & $11,117 \mathrm{~b}$ & 2.2 & Susceptible \\
\hline FPS Solimões RR & $9,391 \mathrm{~b}$ & 1.9 & Susceptible \\
\hline TEC 6702 IPRO & $8,090 \mathrm{c}$ & 1.6 & Susceptible \\
\hline NS 5909 RR & $8,086 \mathrm{c}$ & 1.6 & Susceptible \\
\hline NS 5445 IPRO & $7,155 \mathrm{c}$ & 1.4 & Susceptible \\
\hline 54i52 RSF IPRO & $6,692 \mathrm{c}$ & 1.3 & Susceptible \\
\hline M 6410 IPRO & $6,695 \mathrm{c}$ & 1.3 & Susceptible \\
\hline NS 5959 IPRO & $4,822 \mathrm{~d}$ & 1.0 & Susceptible \\
\hline BMX Elite IPRO & $3,865 \mathrm{e}$ & 0.8 & Resistant \\
\hline NA $6211 \mathrm{RR}$ & $3,680 \mathrm{e}$ & 0.7 & Resistant \\
\hline BMX Valente RR & $3,442 \mathrm{e}$ & 0.7 & Resistant \\
\hline FPS Jupiter RR & $3,405 \mathrm{e}$ & 0.7 & Resistant \\
\hline FPS Iguaçú RR & $2,115 \mathrm{f}$ & 0.4 & Resistant \\
\hline BMX Tornado RR & $2,1025 \mathrm{f}$ & 0.4 & Resistant \\
\hline GMX Cancheiro RR & $2,002 \mathrm{f}$ & 0.4 & Resistant \\
\hline TMG 7161 IPRO & $1,824 \mathrm{f}$ & 0.4 & Resistant \\
\hline TMG 7062 IPRO & $1,800 \mathrm{f}$ & 0.4 & Resistant \\
\hline FPS Solar RR & $1,760 \mathrm{f}$ & 0.4 & Resistant \\
\hline M 5730 IPRO & $1,350 \mathrm{f}$ & 0.3 & Resistant \\
\hline DM5958 RSF IPRO & $887 \mathrm{~g}$ & 0.2 & Resistant \\
\hline NS 6006 IPRO & $810 \mathrm{~g}$ & 0.2 & Resistant \\
\hline SYN 1163 RR & $797 \mathrm{~g}$ & 0.2 & Resistant \\
\hline M 5947 IPRO & $250 \mathrm{~h}$ & 0.0 & Resistant \\
\hline Crotalária $^{5}$ & $40 \mathrm{~h}$ & 0.0 & Resistant \\
\hline
\end{tabular}

Note: ${ }^{1}$ Suceptibility pattern. ${ }^{2}$ Data transformed into square root of $x+0.5 .{ }^{3}$ Means followed by the same letter in the columns belong to the same group (Scott; Knott, 5\% of probability). ${ }^{4}$ Classification proposed by Oostenbrink (1966); ${ }^{5}$ Resistence pattern. 
M. javanica and $M$. incognita species. However, caution must be exercised in the behavior of susceptibility of cultivars, since in addition to the genetic characteristics of the material to be recognized by the nematode and used as a food source, it may be linked to the environmental conditions in which the crop is found ( $\mathrm{Li}$ \& Chen, 2005).

In a work associating control strategies, Araujo et al. (2012) concluded that only the use of a resistant soybean cultivar to $M$. javanica and $M$. incognita did not reduce the incidence of nematodes in the roots neither it increased the dry mass of the aerial part of the plants. On the other hand, the association of resistant cultivars with chemical or biological control provided a reduction in the incidence of nematodes in the roots, and enhanced soybean growth. Similarly, Kamunya et al. (2008) reported that the use of resistant genotypes is undoubtedly the best option, since it is of low cost and agroecologically correct to control nematodes, but nevertheless, the use of other associated techniques can provide better control results.

Information on Brazilian cultivars resistant to the species $M$. javanica and $M$. incognita can be found in the literature, but often in a partial and contradictory way, depending on the criteria used by the researchers (Mendes \& Rodriguez, 2000). Considering the results presented by Kirsch (2016), the author verified that resistance sources are available among the soybean cultivars, for the root-knot nematode species evaluated in her work. However, she emphasizes that there are few evaluated sources of resistance and that the levels are not high. Therefore, the development of a work related to this subject requires accurate and continuous information, since soybean cultivars are made available in the market every year and information on the reaction of the cultivar is one of the main management strategies of the root-knot nematodes.

Table 3: Nematode final population (egg and J2/plant), reproduction factor (RF) and reaction (R) of twenty-seven soybean cultivars to Meloidogyne incognita at 90 days after inoculation

\begin{tabular}{|c|c|c|c|}
\hline Cultivar & Final Population (FP) & Reproduction Factor (RF) & $\begin{array}{c}\text { Classification } \\
4\end{array}$ \\
\hline Tomato $^{1}$ & $137.036 \mathrm{a}^{2,3}$ & 27.4 & Susceptible \\
\hline NS 6211 RR & $34.600 \mathrm{~b}$ & 6.9 & Susceptible \\
\hline BMX Valente RR & $26.616 \mathrm{c}$ & 5.3 & Susceptible \\
\hline AMS Tibagi RR & $25.517 \mathrm{c}$ & 5.1 & Susceptible \\
\hline BMX Tornado RR & $24.825 \mathrm{c}$ & 4.9 & Susceptible \\
\hline NS 6006 IPRO & $24.592 \mathrm{c}$ & 4.9 & Susceptible \\
\hline M 5947 IPRO & $22.975 \mathrm{c}$ & 4.6 & Susceptible \\
\hline FPS Solimões RR & $20.908 \mathrm{~d}$ & 4.2 & Susceptible \\
\hline M 5730 IPRO & $19.890 \mathrm{~d}$ & 3.9 & Susceptible \\
\hline BMX Vanguarda IPRO & $15.575 \mathrm{e}$ & 3.1 & Susceptible \\
\hline 54i52 RSF IPRO & $15.166 \mathrm{e}$ & 3.0 & Susceptible \\
\hline NS 6410 IPRO & $14.915 \mathrm{e}$ & 2.9 & Susceptible \\
\hline BMX Elite IPRO & $12.300 \mathrm{f}$ & 2.5 & Susceptible \\
\hline TEC 6702 IPRO & $12.136 \mathrm{f}$ & 2.4 & Susceptible \\
\hline BMX Ativa RR & $11.160 \mathrm{f}$ & 2.2 & Susceptible \\
\hline FPS Júpter RR & $10.280 \mathrm{f}$ & 2.0 & Susceptible \\
\hline NS 5445 IPRO & $9.135 \mathrm{f}$ & 1.8 & Susceptible \\
\hline TMG 7161 IPRO & $9.085 \mathrm{f}$ & 1.8 & Susceptible \\
\hline NS 5909 RR & $8.961 \mathrm{f}$ & 1.8 & Susceptible \\
\hline GMX Cancheiro RR & $7.065 \mathrm{~g}$ & 1.5 & Susceptible \\
\hline BMX Lança IPRO & $6.750 \mathrm{~g}$ & 1.3 & Susceptible \\
\hline DM 5959 IPRO & $6.367 \mathrm{~g}$ & 1.3 & Susceptible \\
\hline DM5958 RSF IPRO & $6.066 \mathrm{~g}$ & 1.2 & Susceptible \\
\hline NS 6700 IPRO & $5.250 \mathrm{~g}$ & 1.0 & Susceptible \\
\hline FPS Iguaçú RR & $4.047 \mathrm{~h}$ & 0.8 & Resistant \\
\hline FPS Solar IPRO & $3.653 \mathrm{~h}$ & 0.7 & Resistant \\
\hline SYN 1163 RR & $3.025 \mathrm{~h}$ & 0.6 & Resistant \\
\hline TMG 7062 IPRO & $2.995 \mathrm{~h}$ & 0.6 & Resistant \\
\hline Crotalária $^{5}$ & $50 \mathrm{I}$ & 0.0 & Resistant \\
\hline
\end{tabular}

C.V. $\quad 9.2$

Note: ${ }^{1}$ Susceptibility pattern; ${ }^{2}$ Data transformed into square root of $\mathrm{x}+0.5$. ${ }^{3}$ Means followed by the same letters in the column belong to the same group (Scott Knott, 5\% of probability). ${ }^{4}$ Classification proposed by Oostenbrink (1966). 


\section{CONCLUSIONS}

The cultivars BMX Lança IPRO, AMS Tibagi RR, BMX Vanguarda IPRO, NS 6700 IPRO and BMX Ativa RR are susceptible to $M$. javanica and cultivars M 5947 IPRO, SYN 1163 RR, NS 6006 IPRO, DM5958 RSF IPRO, M 5730 IPRO, FPS Solar RR, TMG 7062 IPRO, TMG 7161 IPRO, GMX Cancheiro RR, BMX Tornado RR, FPS Iguaçú RR, FPS Júpter RR, BMX Valente RR, NA6211 RR e BMX Elite IPRO are resistant.

Regarding $M$. incognita, the cultivar NS $6211 \mathrm{RR}$ is susceptible and the cultivars TMG 7062 IPRO, SYN 1163 RR, FPS Solar RR and FPS Iguaçu RR are resistant.

Cultivars TMG 7062 IPRO, SYN 1163 RR, FPS Solar RR and FPS Iguaçú RR are resistant to $M$. javanica and $M$. incognita.

\section{ACKNOWLEDGEMENTS, FINANCIAL SUPPORT AND FULL DISCLOSURE}

To CAPES, UPF and PPGAgro for granting the scholarship. The authors declare that there is no conflict of interest in the publication of this paper.

\section{REFERENCES}

Almeida AMR, Ferreira LP, Yorinori JT, Silva JFV, Henning AA, Godoy CV, Costamilan LM \& Meyer MC (2005) Doenças da soja. In: Kimati H, Amorim L \& Rezende JAM (Eds.) Manual de fitopatologia: doenças das plantas cultivadas. $4^{\mathrm{a}}$ ed. São Paulo, Agronômica Ceres. p. 570-588.

Alves TCU, Silva RA, Borges DC, Motta LCC \& Kobayasti L (2011) Reação de cultivares de soja ao nematoide das lesões radiculares Pratylenchus brachyurus. Revista Biodiversidade, 10:73-79

Bonetti JIS \& Ferraz S (1981) Modificação do método de Hussey e Barker para extração de ovos de Meloidogyne exígua em raízes de cafeeiro. Fitopatologia Brasileira, 06:553.

Dalla Favera D (2014) Cover crops, cultivars and nematicides on Meloidogyne javanica and Pratylenchus brachyurus management in soybean. Tese de Doutorado. Universidade Federal de Santa Maria, Santa Maria. 72p.

Araujo FF de, Bragante RJ \& Bragante CE (2012) Controle genético, químico e biológico de Meloidoginose na cultura da soja. Pesquisa Agropecuária Tropical, 42:220-224.

Deuner CC, Ghissi VC \& Tedesco I (2012) Nematoide de galha. In: Reis EM \& Casa RT (Eds.) Doenças da soja. Passo Fundo, Berthier. p.385-393.

Faria CMDR, Salgado SML, Campos HD, Resende MLV, Campos VP \& Coimbra JL (2003) Mecanismos de ataque e defesa na interação nematóide-planta. In.: Fernandes JM, Prestes AM \& Picinini EC (Ed.). Revisão anual de patologia de plantas. Passo Fundo, RAPP. p.373-410.

Hussey RS \& Barker KR (1973) A comparison of methods colleting inocula of Meloidogyne spp. including a new technique. Plant Disease Reporter, 57:1025-1028.

Juhász ACP, Pádua GP, Wruck DSM, Favoreto L \& Ribeiro NR (2013) Desafios fitossanitários para a produção de soja. Informe Agropecuário, 34:66-75.
Kamunya SM, Wachira FN, Lang'at J, Otieno W \& Sudoi V (2008) Integrated management of root knot nematode (Meloidogyne spp.) in tea (Camellia sinensis) in Kenya. International Journal of Pest Management 54:129-136.

Kirsch VG (2016) Fitonematoides na cultura da soja: levantamento, Caracterização de espécies e reação de cultivares a Meloidogyne spp. Dissertação de Mestrado. Universidade Federal de Santa Maria, Frederico Westphalen. 86p.

Li YH \& Chen SY (2005) Effect of the right gene on population development of H. glycines. Journal of Nematology, 37:168177 .

Mattos VS (2013) Variabilidade genética e agressividade a soja [Glycine max (L.) Merrill] de populações de Meloidogyne spp. do Cerrado e de áreas de cultivo. Dissertação de Mestrado. Universidade de Brasília, Brasília. 81p.

Mendes M de L \& Rodriguez PBN (2000) Reação de cultivares de soja [Glycine max (L.) Merril] aos nematoides de galhas Meloidogyne javanica e $M$. incognita R.1,2,3 e 4. Nematologia Brasileira, 24:211-217.

Miranda DM, Favoreto L \& Ribeiro NR (2011) Nematoides: um desafio constante. In: Siqueri F, Caju J \& Moreira M (Ed.) Boletim de pesquisa de soja 2011. Rondonópolis, Fundação MT. p.400-414.

Moritz MP, Carneiro RG, Santiago DC, Nakamura KC, Pignoni E \& Gomes JC (2008) Estudo comparativo da penetração e reprodução de Meloidogyne paranaensis em raízes de cultivares de soja resistente e suscetível. Nematologia Brasileira, 32:3340 .

Moura RM, Davis EL, Luzzi BM, Boerma HR \& Hussey RS (1993) Postinfectional development of Meloidogyne incognita on susceptible and resistant soybean genotypes. Nematropica, 23:73-86.

Oostenbrink M (1966) Major characteristics of the relation between nematodes and plants. Mededelingen Van De landbouwhogeschool Te Wageningen, 66:01-46.

Santos JM \& Soares PLM (2009) O papel dos genótipos Adr's no manejo de nematoides em sistemas de culturas anuais e na recuperação de pastagens degradadas. InteRural, 27:38-41.

Silva FAZ \& Azevedo CAV (2002) Versão do programa computacional Assistat para o sistema operacional Windows. Revista de Produtos Agroindustriais, 4:71-78.

Silva JFV (2001) Resistência genética da soja a nematóides do gênero Meloidogyne. In: Silva JFV, Mazaffera P, Carneiro RG, Asmus GL \& Ferraz LCCB (Eds.) Relações parasito-hospedeiro nas meloidoginoses da soja. Londrina, Embrapa Soja / Sociedade Brasileira de Nematologia, p. 95-127.

Soares PLM, Santos JM dos, Carvalho RB de, Barbosa BFF, Martinelli PRP \& Paes VS (2016) Controle Biológico de Fitonematoides com Fungos Nematófagos. In: Halfeld-Vieira BA, Marinho-Prado JS, Nechet KL, Morandi MAB \& Bettiol B (Eds.) Defensivos Agrícolas Naturais: Uso e Perspectivas. Brasília, Embrapa. p.177-2013.

Teixeira RA (2013) Reação de cultivares de soja a Meloidogyne incognita e $M$. javanica. Tese de Doutorado. Universidade Federal de Goiás, Goiânia. 60p. 